Twilight of the Idols 



\title{
Twilight of the Idols
}

Hollywood and the Human Sciences in 1920 America

\author{
Mark Lynn Anderson
}

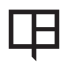

UNIVERSITY OF CALIFORNIA PRESS

Berkeley Los Angeles London 
University of California Press, one of the most distinguished university presses in the United States, enriches lives around the world by advancing scholarship in the humanities, social sciences, and natural sciences. Its activities are supported by the UC Press Foundation and by philanthropic contributions from individuals and institutions. For more information, visit www.ucpress.edu.

University of California Press

Berkeley and Los Angeles, California

University of California Press, Ltd.

London, England

(C) 2011 by The Regents of the University of California

Library of Congress Cataloging-in-Publication Data

Anderson, Mark Lynn, 1960-

Twilight of the idols: Hollywood and the human sciences in 1920 s America / Mark Lynn Anderson.

p. $\mathrm{cm}$.

Includes bibliographical references and index.

ISBN 978-0-520-23711-7 (cloth) — ISBN 978-0-520-26708-4 (pbk.)

1. Motion pictures-Social aspects-United States. 2. Popular cultureUnited States. 3. Motion picture industry-United States-History2oth century. 4. Motion picture actors and actresses-United States.

5. Celebrities-United States. I. Title.

PN1995.9.S6A58 2011

$384.80973-\mathrm{dc} 22$

2010040841

Manufactured in the United States of America

$\begin{array}{llllllllll}20 & 19 & 18 & 17 & 16 & 15 & 14 & 13 & 12 & 11\end{array}$

$\begin{array}{llllllllll}10 & 9 & 8 & 7 & 6 & 5 & 4 & 3 & 2 & 1\end{array}$

This book is printed on Cascades Enviro 100, a 100\% post consumer waste, recycled, de-inked fiber. FSC recycled certified and processed chlorine free. It is acid free, Ecologo certified, and manufactured by BioGas energy. 
For Alice

Wherever you are... 
Denunciation of the misleading seduction of "consumer society" was initially the deed of elites gripped by terror at the twin contemporary figures of popular experimentation with new forms of contemporary life: Emma Bovary and the International Workingmen's Association. Obviously, this terror took the form of paternal solicitude for poor people whose fragile brains were incapable of mastering such multiplicity. In other words, the capacity to reinvent lives was transformed into an inability to judge situations.

-JACQUES RANCIÈRE, “THE MISADVENTURES OF CRITICAL THOUGHT" 